\title{
STUDI EKSPERIMEN PENGARUH PEMANFAATAN SUPERPLASTICIZER TERHADAP KUAT TEKAN DAN PERMEABILITAS BETON BERPORI (PERVIOUS CONCRETE)
}

\author{
Romario W. Pandei ${ }^{1}$, Steve W. M. Supit ${ }^{2}$, Jemmy Rangan ${ }^{3}$, Arthur Karwur ${ }^{4}$ \\ ${ }^{1}$ Mahasiswa Jurusan Teknik Sipil, Politeknik Negeri Manado, Jl. Raya Politeknik, Ds. Buha, Manado, \\ 95252 \\ ${ }^{2,3}$ Dosen Jurusan Teknik Sipil, Politeknik Negeri Manado, Jl. Raya Politeknik, Ds. Buha, Manado, 95252 \\ ${ }^{4}$ Dosen Jurusan Administrasi Bisnis, Politeknik Negeri Manado, Jl. Raya Politeknik, Ds. Buha, Manado, \\ 95252 \\ Email: 2stevewmsupit@gmail.com
}

\begin{abstract}
The application of pervious concrete has been increasing in the area of civil engineering to be one of the alternative solutions in reducing stormwater run-off and prevents flooding. This research aims to investigate the compressive strength and permeability of pervious cement concrete with various of cement:aggregate ratio $=1: 2,1: 4$ and 1:6, and at a water cement ratio of 0.3 . The proportion that obtained highest compressive strength at 7 days was then selected to investigate the effect of superplasticizer addition in pervious concrete based on the results of compressive strength test at 7,14 and 28 days, and void ratio test at 7 and 28 days. The infiltration rate test was also conducted according to ASTM C1701-standard to analyse the permeability level of pervious concrete with and without superplaticizer. The results show that the optimum compressive strength of pervious concrete at 7 days peaked at $5.67 \mathrm{MPa}$, reached by the mixtures with cement:aggregate ratio $=1: 2$. The addition of $0.5 \%$ superplasticizer by weight of cement in this mixture was found effective in improving the compressive strength of pervious concrete up to 8.51 MPa, 10.92 MPa and 13.47 MPa at 7, 14 and 28 days, respectively. It can be concluded that the use of superplasticizer has an effect in increasing the bonding between aggregate-paste and therefore, improves the compressive strength and balance the permeability properties of pervious cement concrete.
\end{abstract}

Key words : Pervious concrete, compressive strength, void ratio, permeability, superplasticizer

\begin{abstract}
ABSTRAK
Aplikasi beton berpori semakin mendapat perhatian di bidang Teknik Sipil karena dapat dijadikan sebagai salah satu solusi untuk mengurangi limpasan air hujan dan mencegah banjir. Penelitian ini bertujuan untuk mengivestigasi karakteristik beton berpori berdasarkan pengujian kekuatan tekan dan permeabilitas beton dengan variasi campuran komposisi semen:agregat = 1:2. 1:4 dan 1:6 dan FAS = 0,3. Dari komposisi campuran yang menghasilkan kuat tekan tertinggi pada 7 hari, dilakukan penelitian lanjutan dengan menggunakan bahan tambah superplasticizer untuk pengujian kuat tekan umur beton 7, 14, dan 28 hari serta pengujian porositas pada umur 7 dan 28 hari. Pengujian laju infiltrasi juga dilakukan berdasarkan standard ASTM C1701 untuk mengevaluasi tingkat permeabilitas beton berpori dengan dan tanpa menggunakan superplasticizer. Hasil penelitian menunjukkan bahwa kuat tekan optimum beton berpori pada umur 7 hari dihasilkan oleh campuran semen:agregat = 1:2 dengan nilai sebesar 5,67 MPa. Penambahan superplasticizer sebesar 0.5\% dari berat semen pada komposisi campuran ini menghasilkan nilai kuat tekan beton berpori berturut-turut sebesar 8,51 MPa, 10,92 MPa dan dan 13,47 MPa pada umur beton 7, 14 dan 28 hari. Penggunaan superplasticizer pada komposisi yang tepat disimpulkan memiliki pengaruh dalam meningkatkan ikatan antara agregat dan pasta semen sehingga memperbaiki karakteristik kuat tekan beton berpori dan tingkat permeabilitasnya.
\end{abstract}

Kata kunci : Beton berpori, kuat tekan, porositas, permeabilitas, superplasticizer 


\section{PENDAHULUAN}

Seiring dengan berkembangannya teknologi beton, penelitian tentang beton tanpa pasir atau disebut juga beton berpori semakin mendapat perhatian akhir-akhir ini. Beton berpori (pervious concrete) merupakan salah satu jenis beton yang dikategorikan sebagai beton ringan karena adanya pengurangan agregat halus. Bahkan dalam beberapa penelitian sudah tidak lagi menggunakan pasir sehingga membuat massa beton itu sendiri menjadi ringan dari beton konvensional pada umumnya.

Beberapa keuntungan pemanfaatan beton porous adalah sebagai berikut (Bayuaji, 2011):

1. Memiliki workability yang baik sehingga mudah dalam proses pelaksanaan. Sifat ini menjadikan pelaksanaan beton porous dapat mengisi celah antar tulangan dan tidak memerlukan proses pemadatan yang berarti di lapangan.

2. Pelaksanaan beton porous membutuhkan mobilisasi yakni transportasi dan jumlah operator yang lebih sedikit karena beratnya yang lebih ringan dari beton normal.

3. Beton porous menyerap panas yang baik dan tahan api serta menjadi peredam beban kejut yang baik.

4. Memiliki berat yang ringan sehingga secara struktur dapat mengurangi berat sendiri dan memiliki dimensi elemen struktur yang lebih berkurang.

Beton berpori atau pervious concrete tersusun atas dua elemen pembentuk utamanya yaitu, semen dan agregat kasar. Tidak adanya penggunaan agregat halus membuat beton memiliki rongga pada strukturnya. Hal inilah yang membuat beton berpori menjadi mudah dilewati oleh air. Berdasarkan ACI 522R-10, beton berpori terbentuk dari campuran semen Portland, sedikit atau tidak sama sekali agregat halus, agregat kasar, dan bahan tambah (admixture), serta air. Nilai slump pada beton berpori berbeda dengan beton pada umumnya, yakni nilainya yang mendekati nilai nol.

Pengaplikasian beton berpori pada umumnya masih terbatas untuk konstruksi jalan, area pejalan kaki maupun tempat parkir dimana dengan prosentasi rongga pada beton berkisar antara $12 \%$ sampai $25 \%$ (Zulfikar, 2010). Dengan kadar rongga ini, memungkinkan air yang ada dipermukaannya langsung terserap kedalam tanah sehingga dapat mengurangi limpasan air hujan.

Adapun dalam pengembangan penelitian beton porous, beberapa hasil penelitian dapat diuraikan berikut ini. Sari (2013) melalui penelitian tentang Pengaruh Komposisi Beton Non Pasir dengan Subtitusi Fly Ash dan Superplasticizer Terhadap Kuat Tekan, Modulus Elastisitas, dan Daya Serap Air, menemukan bahwa penggunaan fly ash sebesar 20\% dan Superplasticizer $0.6 \%$ dapat meningkatkan kuat tekan beton non pasir pada umur 28 hari. Penelitian lain adalah dengan sistim subtitusi semen dengan material pozzolan. Contohnya penelitian Suseno (2017), yang meneliti pemanfaatan abu terbang yang disubstitusikan sebagian terhadap semen dengan prosentase $0 \%$, $15 \%$ dan 25\%, dan dikombinasikan pada beton porous dengan campuran agregat kasar daur ulang. Menurut penelitian ini diperoleh bahwa beton porous dengan $25 \%$ abu terbang dan $0 \%$ agregat daur ulang menghasilkan kekuatan tertinggi sebesar 13,621 $\mathrm{MPa}$ sementara beton porous tanpa penggunaan abu terbang dan agregat kasar daur ulang hanya memiliki kekuatan tekan sebesar 5,459 MPa. Penelitian lain adalah dengan 
menggunakan SikaCim Concrete Additive sebesar $7,5 \mathrm{ml} / \mathrm{kg}$ semen dan mengkombinasikannya dengan styrofoam yang digunakan sebagai bahan pengisi beton porous. Hasil penelitian Ginting (2015) menunjukkan pengaruh faktor air semen terhadap peningkatan kuat tekan dari beton porous dengan styrofoam dimana faktor air semen $=0,3$ menghasilkan kuat tekan terendah 8,11 MPa dan tertinggi sebesar 14,97 MPa sedangkan faktor air semen $=0,25$ menghasilkan kuat tekan terendah sebesar 7,37 MPa dan tertinggi 8,87 MPa. Penelitian Darwis, dkk (2017) meneliti tentang perbandingan penggunaan semen dengan agregat 1:4, 1:6, 1:8, 1:10 dan diperoleh nilai kuat tekan optimum pada rasio semen agregat 1:6 adalah 3,712 MPa dan kuat lentur tertinggi 0,963 $\mathrm{MPa}$.

Walaupun pemanfaatannya sudah mulai tersebar luas karena menghasilkan beton yang lebih ekonomis, namun masalah kekuatan beton berpori yang relatif rendah dibandingkan dengan beton normal masih perlu diteliti lebih lanjut, salah satunya tentang pengaruh pemanfaatan superplasticizer (SP) terhadap karakteristik beton berpori. Tujuan penelitian ini adalah untuk menginvestigasi pengaruh pemanfaatan superplasticizer berdasarkan nilai kuat tekan beton berpori pada umur 7, 14 dan 28 hari dan nilai permeabilitas pada umur 7 hari.

\section{METODE PENELITIAN}

Metode penelitian yang digunakan adalah kajian eksperimental yang dilaksanakan di Laboratorium Uji Bahan Jurusan Teknik Sipil Politeknik Negeri Manado, dengan perencanaan campuran beton berpori dapat dilihat pada Tabel 1.
Tabel 1. Proporsi Campuran Beton / $\mathrm{m}^{3}$

\begin{tabular}{cccccc}
\hline $\begin{array}{c}\text { Kode } \\
\text { Beton }\end{array}$ & $\begin{array}{c}\text { Komposisi } \\
\text { Campuran }\end{array}$ & $\begin{array}{c}\text { Semen } \\
(\mathrm{kg})\end{array}$ & $\begin{array}{c}\text { Kerikil } \\
(\mathrm{kg})\end{array}$ & $\begin{array}{c}\text { Air } \\
(\mathrm{kg})\end{array}$ & $\begin{array}{c}\text { SP } \\
(\mathrm{kg})\end{array}$ \\
\hline PN-2 & $1: 2$ & 400 & 800 & 100 & 0 \\
PN-4 & $1: 4$ & 400 & 1600 & 100 & 0 \\
PN-6 & $1: 6$ & 400 & 2400 & 100 & 0 \\
PSp-2 & $1: 2$ & 400 & 1600 & 100 & 20 \\
\hline
\end{tabular}

Penelitian dilaksanakan dengan dua tahap. Tahap satu dilakukan pengujian kuat tekan pada umur 7 hari dengan variasi campuran tanpa menggunakan superplasticizer, dimana rasio semen: agregat adalah 1:2, 1:4 dan 1:6. Pada pengujian tahap dua, dipilih campuran yang mencapai kuat tekan tertinggi pada umur beton 7 hari untuk diuji pengaruh pemanfaatan superplasticizer sebanyak 0,5\% dari berat sement terhadap kuat tekan beton berpori pada umur 7, 14 dan 28 hari. Sedangkan tahap tiga adalah pengujian permeabilitas untuk meneliti laju infiltrasi beton berpori dengan menggunakan SP 0,5\%.

Sampel yang diuji terhadap kuat tekan adalah berbentuk silinder dengan ukuran diameter $100 \mathrm{~mm}$ dan tinggi 200mm (Gambar 1), sedangkan pengujian permeabilitas menggunakan benda uji berbentuk pelat beton dengan ukuran 400x600x50mm (Gambar 2).

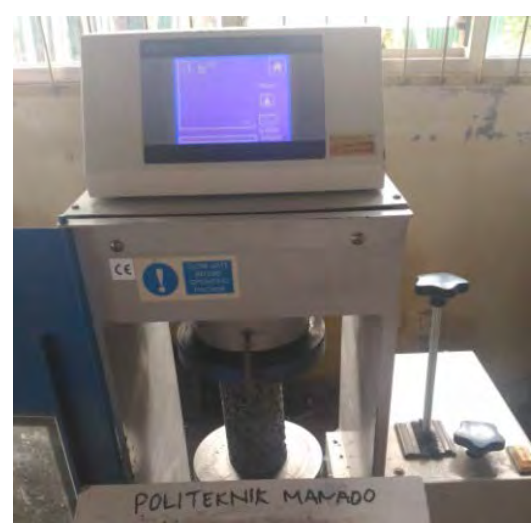

Gambar 1. Sampel Silinder untuk Pengujian Kuat Tekan Beton Berpori 


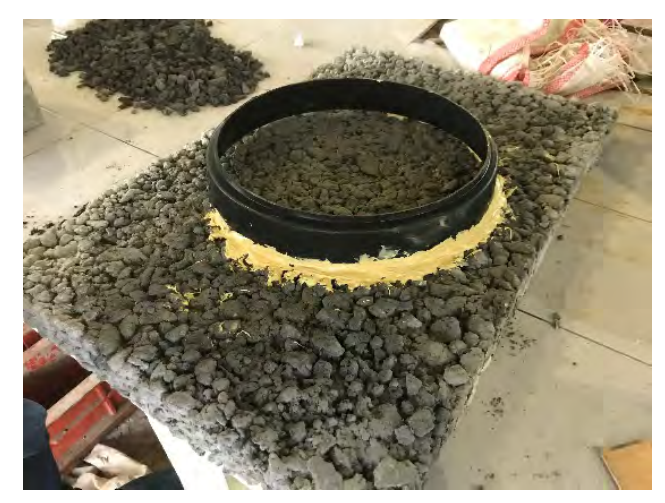

Gambar 2. Sampel untuk Pengujian Laju Infiltrasi Beton Berpori

Sehari sebelum pengujian, sampel dikeluarkan dari bak perendaman. Sebelum dilakukan pengujian, timbang berat sampel. Pengujian kuat tekan beton dilakukan dengan menggunakan Strength Compressive Machine berkapasitas $3000 \mathrm{KN}$.

Rumus yang digunakan untuk mendapatkan nilai kuat tekan beton dapat dilihat pada persamaan (1) sebagai berikut:

$f^{\prime} c=\frac{\mathrm{P}}{\mathrm{A}}$

Keterangan:

$f^{\prime} \mathrm{C}=$ Kuat tekan $(\mathrm{MPa})$

$\mathrm{P}=$ Beban tekan $(\mathrm{N})$

$\mathrm{A}=$ Luas penampang benda uji $\left(\mathrm{mm}^{2}\right)$

Selain pengujian kuat tekan, dilakukan juga uji permeabilitas untuk mengetahui berapa lama air dapat tembus melewati beton berpori dengan satuan $\mathrm{mm} /$ detik. Untuk menjaga air yang dituang ke permukaan beton berpori tetap konstan maka penuangan dibatasi oleh ring dengan diameter $300 \mathrm{~mm}$ dan tinggi $\geq$ $50 \mathrm{~mm}$ yang ditempelkan dengan menggunakan bahan perekat (lihat Gambar 3). Metode pengujian ini dilakukan berdasarkan ASTM C1701 (Standard Test Method for Infiltration Rate of In Place Pervious Concrete).

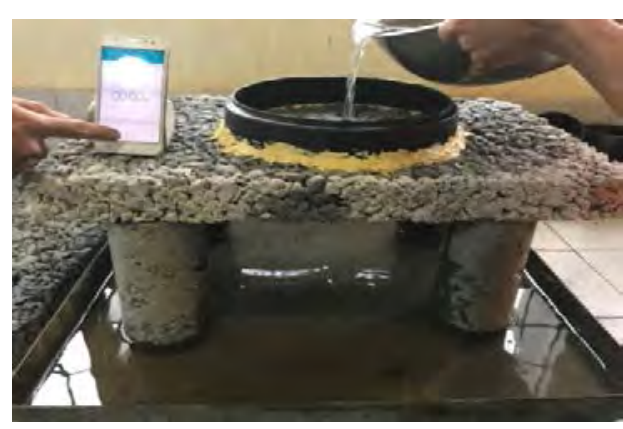

Gambar 3. Metode Pengujian Laju Infiltrasi Beton Berpori

Adapun rumus pengujian permeabilitas/infiltrasi dapat dilihat pada persamaan (2) sebagai berikut:

$I=\frac{K M}{D^{2} t}$

Keterangan:

$I=$ Laju infiltrasi $(\mathrm{mm} / \mathrm{jam})$

$D \quad=$ Diameter bagian dalam ring (30 $\mathrm{mm}$ )

$t=$ Waktu yang dibutuhkan untuk meloloskan air $\left(\mathrm{m}^{3}\right)$

$K=$ Konstanta dengan nilai 4.583.666.000 ((mm² detik)/(kgjam))

\section{HASIL dan PEMBAHASAN}

Hasil pengujian kuat tekan beton berpori berikut merupakan nilai ratarata dari tiga sampel pada masingmasing variasi campuran pada umur 7 hari yang kemudian dibuatkan dalam bentuk grafik seperti terlihat pada Gambar 4.

Berdasarkan Gambar 4 terlihat bahwa nilai kuat tekan tertinggi dicapai oleh beton dengan rasio semen:agregat 1:2 (PN-2) yakni sebesar 5,67 MPa. Sedangkan kuat tekan beton PN-4 dan PN-6 berturut-turut adalah 3,63 dan 2,43 MPa. Prosentasi kenaikan kuat tekan beton PN-2 adalah sebesar 56\% dan 133\% lebih tinggi dari PN-4 dan PN-6. Dari hasil kuat tekan ini, dipilih campuran $\mathrm{PN}-2$ dengan rasio:agregat 1:2 untuk diteliti kuat tekannya setelah diberikan penambahan superplasticizer $0,5 \%$ dari berat semen. 


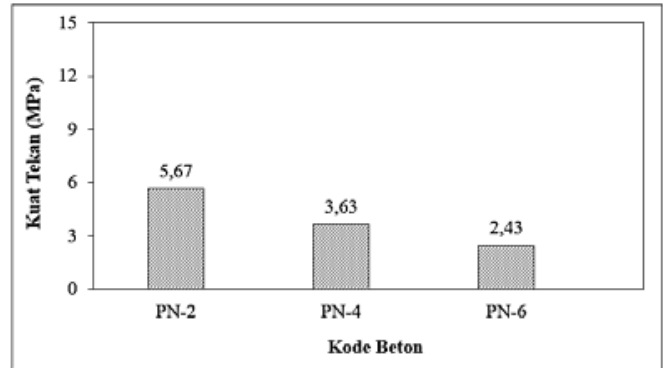

Gambar 4. Hasil Kuat Tekan Beton Berpori Umur 7 Hari

Gambar 5 menunjukkan hasil kuat tekan beton berpori dengan campuran rasio semen:agregat 1:2 dengan menggunakan $\quad 0,5 \%$ superplasticizer (PSp-2), dimana nilai kuat tekan beton berpori PSp-2 memiliki kuat tekan yang lebih tinggi dari PN-2 pada umur 7 hari dengan nilai kuat tekan adalah 8,51 $\mathrm{MPa}$ dengan peningkatan yang diperoleh adalah sebesar 50\%. Hal ini mengindikasikan bahwa 0,5\% superplasticizer memiliki pengaruh yang cukup signifikan dalam menambah ikatan antar agregat sehingga mempengaruhi peningkatan ketahanan beton berpori terhadap beban tekan. Pada umur 14 dan 28 hari, kuat tekan PSp-2 adalah sebesar 10,92 $\mathrm{MPa}$ dan 13,47 MPa. Dimana hasil ini belum mencukupi nilai minimal $15 \mathrm{MPa}$ yang distandarkan oleh SNI 03-0691-1996 untuk standar mutu bata beton. Walaupun demikian, hasil penelitian ini dapat dijadikan sebagai acuan untuk perbandingan dengan kuat tekan beton tanpa superplasticizer pada pengujian lanjutan. Disamping itu dalam kaitannya dengan kuat tekan beton berpori, diperlukan kontrol dosis superplasticizer dalam campuran. Hal ini dikarenakan penggunaan bahan tambah chemical admixture berupa superplasticizer pada beton berpori dapat mempengaruhi tingkat kelecakan (workability) beton tersebut, dimana penggunaan dosis yang terlalu banyak akan menyebabkan kuat tekan beton berpori menjadi menurun (Siregar, 2014).

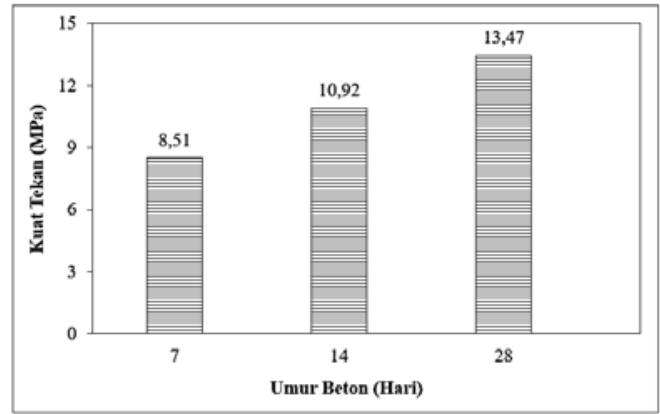

Gambar 5. Hasil Kuat Tekan Beton Berpori dengan 0,5\% Superplasticizer

Gambar 6 menunjukkan nilai hasil pengujian permeabilitas atau pengukuran laju infiltrasi menggunakan campuran 1:2 dengan penambahan $0.5 \%$ superplasticizer. Infiltrasi dapat diartikan sebagai proses masuknya air dari permukaan (surface) yang disebabkan oleh gaya kapiler (gerakan air ke arah lateral) dan gravitasi (gerakan air ke arah vertikal).

Pada penelitian ini, hasil pengujian diperoleh dari tiga kali pengujian dengan metode yang sama sesuai yang diuraikan sebelumnya. Dari tiga kali pengujian ini diperoleh hasil sebagaimana yang terlihat pada Gambar 6, dimana pada pengujian pertama diperoleh nilai laju infiltrasi adalah sebesar 6,44 mm/detik. Pada pengujian kedua dan ketiga diperoleh juga hasil yang tidak jauh berbeda yakni sebesar 6,11 $\mathrm{mm} /$ detik dan 6,33 $\mathrm{mm} /$ detik, dengan rata-rata diperoleh 6,29 $\mathrm{mm} /$ detik. Hasil ini berada dalam range yang ditetapkan ACI 522R (2010) yakni 1,4-12,2 mm/detik. Namun, dalam penelitian ini tidak dilakukan pengujian infiltrasi terhadap beton berpori tanpa menggunakan SP, sehingga diperlukan penelitian lanjutan untuk membandingkan hasil laju infiltrasi yang diperoleh. Meninjau beberapa penelitian sebelumnya, penggunaan superplasticizer pada beton berpori akan memberikan kontribusi dalam menigkatkan ketebalan pasta semen yang dapat mengurangi laju perkolasi 
dengan berkurangnya porositas. Hal ini dapat memberikan pengaruh posistif yang salah satunya adalah peningkatan kekuatan tekan (Torres dkk, 2015).

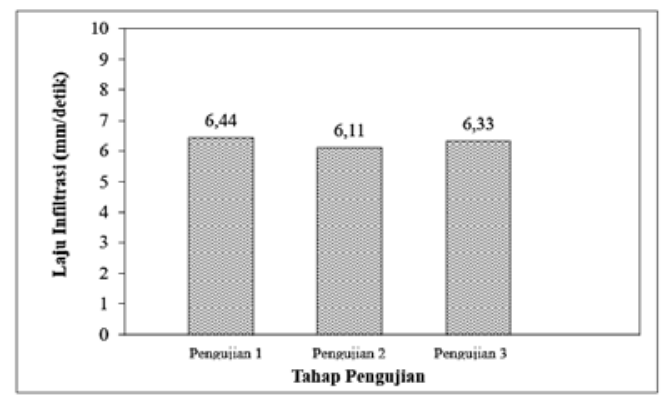

Gambar 6. Pengujian Permeabilitas Beton Berpori

\section{KESIMPULAN}

Dari hasil penelitian yang sudah dilaksanakan maka dapat diambil kesimpulan sebagai berikut:

1. Komposisi campuran dengan rasio semen:agregat 1:2 mencapai kuat tekan tertinggi pada umur 7 hari dibandingkan campuran dengan rasio semen:agregat 1:4 dan 1:6. Semakin besar perbandingan campuran semen dengan agregat kasar maka semakin kecil nilai kuat tekan yang akan dihasilkan.

2. Penambahan $0.5 \%$ superplasticizer pada beton berpori campuran 1:2 dapat menghasilkan kuat tekan sampai 8,51 MPa pada umur 7 hari, 10,92 MPa pada umur 14 hari, dan 13,47 MPa pada umur 28 hari. Hasil ini belum mencukupi persyaratan kuat tekan minimal untuk aplikasi bata beton sesuat standar SNI 03-0691-1996, namun masih masuk dalam kategori kuat tekan beton berpori.

3. Beton berpori dengan penambahan 0,5\% superplasticizer mencapai laju infiltrasi rata-rata sebesar 6,29 $\mathrm{mm}$ /detik. Hasil ini berada dalam range laju infiltrasi yang ditetapkan
ACI 522R (2010) yakni 1,4-12,2 $\mathrm{mm} /$ detik.

4. Perlu dilakukan penelitian lanjutan untuk membandingkan pengaruh penambahan superplasticizer pada umur beton berpori 14 dan 28 hari, terhadap uji kuat tekan dan laju infiltrasi.

\section{UCAPAN TERIMAKASIH}

Penulis menyampaikan banyak terima kasih kepada Politeknik Negeri Manado melalui bantuan dana Penelitian Internal Produk Terapan Tahun 2018 sehingga penelitian ini bisa dilaksanakan.

\section{DAFTAR PUSTAKA}

[1] ACI Commitee 522R-10. 2010. Report on Pervious Concrete 522R10. Farmington Hils: American Concrete Institude.

[2] ASTM C 1701. 2009. Standard Test Method for Infiltration Rate of In Place Pervious Concrete. ASTM International.

[3] Arnoldus, F. 2010. Studi Analisa Pengaruh Dimensi Agregat Terhadap Nilai Kuat Tekan dan Tingkat Porositas Air Untuk Beton Berpori dengan Bahan Tambah Fly Ash Pada Aplikasi Sidewalk. Skripsi S1 Jurusan Teknik Sipil. Jakarta: Univ. Bina Nusantara.

[4] Darwis, Z, Baehaki, Suptiyadi, H. 2017. Beton Non-Pasir dengan Penggunaan Agregat Lokal dari Merak. Jurnal Fondasi Jurusan Teknik Sipil Universitas Sultan Ageng Tirtayasa, Volume 6 No.1.

[5] Ginting, A. 2015. Kuat Tekan dan Porositas Beton Porous dengan Bahan Pengisi Styrofoam. Jurnal Teknik Sipil, Vol. 11, No. 2, Oktober 2015; 76-168.

[6] Sari, P, E, D. 2013. Pengaruh Komposisi Beton Non Pasir dengan Substitusi Fly Ash dan Superplasticizer Terhadap Kuat 
Tekan, Modulus Elastisitas, dan daya Serap Air. Skripsi S1 Program Studi Teknik Sipil. Yogyakarta: Univ. Atma Jaya.

[7] Siregar, P. 2014. Kajian Penambahan Metakaolin Terhadap Kuat Tekan dan Modulus Elastisitas Pada Beton Mutu Tinggi dengan Silica Fume, Superplasticizer dan Filler Pasir Kwarsa. Skripsi S1 Program Studi Teknik Sipil. Yogyakarta: Univ. Atma Jaya.

[8] SNI-03-0691-1996 tentang Bata Beton (Paving Block).

[9] Zulfikar, dan Karolina, R. 2010. Kajian Pendahuluan Beton Lolos Air (Porous Concrete) dengan Penambahan Masterroc HCA10. Jurnal Teknik Sipil USU, Departemen Teknik Sipil. Medan: Univ. Sumatera Utara.

[10]Torres, A, Hu, J, dan Ramos, A. 2015. The Effect of The Cementitious Paste Thickness on The Performance of Pervious Concrete. Construction and Building Materials, Vol. 95. P.p. 850-859. 
Romario W. Pandei dkk, Studi Eksperimen Pengaruh... 